DOI https://doi.org/10.36059/978-966-397-201-5/93-112

\title{
POLYSTYLISTICS AS A MUSICAL PHENOMENON AND ITS AUTHOR'S MODELS
}

\section{Grybynenko Ju. 0.}

\section{INTRODUCTION}

The XX century, ending and moving towards the third millennium, performs a difficult task. On the one hand, it is an extension of cognition methods (both in science and in art) associated with the desire to cover many information flows; on the other, it is an already completed transition to a new millennium and readiness for it, and hence the increased role of psychological knowledge, designed to explain the future possibilities of the evolution of human consciousness - as its possibility for life in the future.

Transformation on the new basis of leading ideas of the past has always been one of the main links in the artistic and aesthetic process. The phenomena that arise on the border of continuity and innovation actively influence the development of any direction in art. In the XX century, these phenomena in the context of new style searches are developing widely and in diverse ways. Some of them have long been entrenched in composer's practice, but even today they continue to remain insufficiently studied. Therefore, the identification and analysis of style trends diversity in composer's creative work in the second half of the XX and the beginning of the XXI centuries is becoming especially relevant for modern musicology. It is known that this period in art does not represent a single historical style. It is formed by various trends and directions, what gives reason to talk about the "pluralism" of musical culture in these decades, about the complex stylistic conglomerate of this era; the desire for stylistic universality seems to be one of the most important stylistic aspects of the art of this period as a whole.

In music today there is a process of synthesizing, summarizing previously found genre and style realities; in the compositionally unified the different (according to the linguistic possibilities of music) combines, and in various stylistic tendencies a new desire for methodological unity is manifested. As a historical phenomenon, at the beginning of the XX century the musical and creative process is at the final stage summing up results, so far without a clear anticipation of fundamental 
changes. However, it is from the side of the individual composer's style that the new essential properties of artistic synthesis appear, leading to the polysystem of musical thinking and openness not only of compositional (as P. Boulez interpreted it), but also of the stylistic form of music. As a result of this, associative independence, figurative and semantic initiative of the author's style, based on the variety of style interaction forms, is increasing.

The composer's work of the second half of the XX century and the beginning of the XXI centuries is largely aimed at integrating a wide genre and style spectrum of musical layers of the most diverse eras. M. Aranovsky, pointing out this quality of modern composer's poetics, emphasized that fragments of styles in the process of creating a musical composition fulfill the functions of components with a "set value", which opens up the possibility for the composer to operate with them as with signs. At the same time, "the entire stylistic spectrum of the history of European music becomes the subject of artistic reflection" from the side of the author ${ }^{1}$, as a result of which the "stylistic layering" of the text is formed. In domestic and foreign academic music of the indicated period, this tendency is embodied in the method of polystylistics - a symbolic expression of the multiplicity of musical consciousness, a leading composer's method that meets the author's conscious intention to introduce his design into the general style context of music.

\section{Polystylistics in the light of musicological reflections}

The musical and artistic phenomenon - polystylistics, which introduced new historical and cultural dimensions and its artistic possibilities into music, - causes active discussions up to this day. The appearance of this term is legitimate and necessary, since in the last decades of the XX century polystylistics took shape in a conscious manner, established itself as a stylistic multiplicity, complexity, internal contrast of one composition, that is, as a compositional phenomenon. In this regard, it is interesting to compare the phenomenon of polystylistics with the "two-voiced word" in its coverage by M. Bakhtin. As a kind of author's utterance, such a "word" reflects the author's ability to use alien word for his own purposes, to invest a new semantic orientation in the "word", which already has its own orientation and preserves it.

1 Арановский М. Музыкальный текст: структура и свойства. М., 1998. C. $157-159$. 
Moreover, such a word, according to an assignment, should be felt like alien. Of particular interest in this connection is "hidden polemic: "alien word" is repelled, and this repulsion is not less than the very subject in question defines the author's word",2. Hidden polemics is sometimes unusually vividly reflected in music, when the element of reaction to the previous style, present in each new style, is the same internal polemic, so to say, a hidden anti-stylization of alien style, often combined with mimicking it. Polystylistics as a kind of protest against the thoughtless assimilation of traditions owes this to polemic with tradition.

If since the $60 \mathrm{~s}$ of the XX century, the time of the polystylistic "explosion", the main goal in comprehending the phenomenon has been the study of musical "matter" (qualities and levels of assimilation of borrowed material), then the most relevant is the in-depth study of the semantic content of polystylistics, the search for those aspects that will help to comprehend the stylistic essence of modern musical culture, as well as to reveal in the principles of variability of the "alien text" the influence of some general cultural trends.

$\mathrm{V}$. Kholopova notes that European culture of the XX century is notable for its severe breakdown into many isolated subcultures. In parallel and independently from each other, according to the author, there is a classical heritage of different eras, avant-garde experimentation, jazz, pop and rock music, pop music, European folklore, cult music, mass songs, electronic and specific music, traditional music of non-European countries, etc. "At the same time, the avant-garde, which had completely dried itself out in a pointillistic («point») style, and the stage-jazz style, unchained to a physical gesture, made up mutually exclusive poles of culture" 3 .

Similar situations of gaps in culture arose in the past, and not only in music. According to literary scholars, the position of the verbal language in Russia in the first decades of the XIX century, when there was a language of fiction, colloquial, clerical, military languages, the language of theological literature, etc., but no single Russian language, could serve as an analogy. This state of the language created many obstacles to the development of Russian society, its thinking. The writer who combined all these languages was N.V. Gogol. Gogol's literary and linguistic

2 Бахтин М. Собрание сочинений в семи томах. Проблемы поэтики Достоевского. Том 6. М.: Русские словари, 2002. С. 219.

${ }^{3}$ Холопова В. Композитор Альфред Шнитке. Челябинск: «Аркаим», 2001. C. 90 . 
reform had an enormous progressive social meaning. And in terms of art, the language of the great writer revealed the inexhaustible resources of the play with stylistic components - speech stylistic layers, that is, the resources of verbal and language polystylistics ${ }^{4}$.

The source of musical polystylistics can be considered the "one-time contrast technique", which, having established itself in the music of J.S. Bach, becomes one of the most important principles of style formation in the future history of music. The term "one-time contrast", proposed by T. Livanova, is interpreted by E. Nazaikinsky as "something complex, mediated by physiology, psychology, culture and, at the same time, directly infecting, involving in empathy, cathartic state"5. The author emphasizes that "this is not a contrast in the literal sense of the word. There are no sharply delimited and disjoint planes, there are no parallel, but different in character and sound properties components of the texture ..." And if they are, then most often they are not perceived as opposing, since they are subordinate to the unity of harmonious, rhythmic, textured organizations. The special nature of the relationship of the contrasting parties cannot be unambiguously defined by the concept of coordination or subordination; here is more likely a single combat, an inextricable interweaving of hostile forces, which is not so much perceived as directly experienced. "The "contrast" here is a metaphor"; "Forces ... engage in a battle that engenders a static but tense expression observed from the outside" .

A specific feature of modern musical culture is the oncoming movement of composer's and musicology thought in search for new nominations of composer's poetics. Quite often, it is in the field of compositing judgments that promising theoretical positions are formed, since composer's consciousness feels the need for self-determination in theoretical assessment. A vivid example of what has been said is Alfred Schnittke's report, "Polystylistic Trends in Contemporary Music", made at the MMS congress on October 8,1971, in which the concept and term "polystylistics" were first declared by the theoretic and composer and two polar principles of using "alien style" were outlined: the principle of

\footnotetext{
${ }^{4}$ Там же.

5 Назайкинский Е. Принцип единовременного контраста. Русская книга о Бахе. М.: Музыка, 1985. С. 277.

6 Там же, С. 275.

7 Там же, С. 275.
} 
citation and the principle of allusion ${ }^{8}$. The composer, in the compositions of whom there are a lot of different stylistic innovations, turning to the music of other masters, builds a theoretical base for his own creative finds. He introduces the terms polystylistics, allusion, adaptation, considers the concepts of collage, quotation, citation, and parses a number of musical samples. E. Nazaykinsky focuses on the fact that at first glance, it may seem that the definition of polystylistics by A. Schnitke is only a peripheral of philological interpretations of stylistics - a well-known and approved term. Indeed, the style of the work reflects the use of several different style components in its compositional and semantic structure. And the Greek prefix of the term (poly-) introduced by A. Schnittke just indicates their multiplicity. But is this indication really necessary? Indeed, monostylistics does not exist in real artistic practice. Polystylistics is a necessary "nutrient" medium of music of any era. The composer himself justifies the feasibility of introducing a new term, treating polystylistics as a special type of style, raised in the $\mathrm{XX}$ century to the level of leading compositional technique ${ }^{9}$.

Alfred Schnittke asks the question: "... Is the word "polystylistics" acceptable in relation to the elusive play of temporal and spatial associations, inevitably inspired by music? Indeed, in a hidden form, a polystylistic tendency exists and existed in any music, because stylistically sterile music would be dead. So is it worth talking about it? ${ }^{10}$. And he himself answers: "It is necessary to talk about it, because in the last decade the polystylistics has taken shape in a conscious manner without even quoting, the composer plans in advance a polystylistic effect, whether it is the effect of the shock from a collage of musical times, whether it's slipping through the phases of musical history, or the subtlest, as it were, random allusions" $"$.

According to E. Nazaykinsky, the main motive for introducing a new term (polystylistics) was the need for the composer to give a name to the modern stylistic composition technique. As a matter of fact, this technique is not so new; the conscious, purposeful use of complex stylistic comparisons and relationships, of course, was encountered in

${ }^{8}$ Холопова В., Чигарева Е. Альфред Шнитке: Очерк жизни и творчества. М.: Советский композитор, 1990.

${ }^{9}$ Там же.

${ }^{10}$ Там же, С. 329.

${ }^{11}$ Там же, С. 329. 
composer's practice long before the avant-garde artists of the XX century. Perhaps, only a somewhat more intense and sharper handling of the stylistic components of the composition nevertheless gives reason to add to the terms polytonality, polytimberness, polyrhythmia and also polystylistics, characteristic of the era ${ }^{12}$.

The definition of polystylistics in the Encyclopedic Dictionary of Music (1991) introduces another trait that A. Schnittke does not have. This phenomenon is interpreted as "an intentional combination of incompatible (or at least sharply different, heterogeneous) stylistic elements in one composition". It is clear that this definition somewhat changes the content of the concept, limiting polystylistics only to contrasting stylistic elements ${ }^{13}$. After all, A. Schnittke spoke not only about "shock" comparisons, which were especially effective in "gluing" (collage) dissimilar texts, but also about soft allusion, imperceptible stylistic modulations. The main thing for him was to give a name to the special modern compositional technique.

A significant contribution to the development of the problem of polystylistics became the works of G. Grigorieva, in which the musicologist suggested using the term eclecticism (borrowed from architecture), interpreted as a method of active style interactions. The author pointed to the specification of the composer's technique of working with the material as a factor of poly-and monostylistics, as well as the fact that the polystylistic technique follows a rather intensive development path and modulates the new component into monostylistics, where the "musical galaxy" of the attracted material is not aimed at sharpening contrasts, but, on the contrary, at their smoothing ${ }^{14}$.

The works of V. Kholopova are also associated with the development of the theory of polystylistics. The musicologist considers this phenomenon as a method of creativity, determining various types of musical semantics, which, according to $\mathrm{V}$. Kholopova, gives an opportunity, summarizing the multiple semantic data, to distinguish three leading types of polystylistics: diffuse, collage, and pluralistic. The first type, in her opinion, is characterized by a smooth transition from one

12 Назайкинский E. Стилистика музыкального произведения. URL: www.harmony.musigi.dunya.az/harmony/rus

13 Энциклопедический музыкальный словарь. М., Советская энциклопедия, 1990. C. 431.

14 Григорьева Г. Стилевые проблемы русской советской музыки второй половины ХХ века. М., Советский композитор, 1989. 
style element to another, by the stylistic dispersion of the original thematic complex. The second type is characterized by contrast, sometimes a sharp ("shock") juxtaposition of style elements. Pluralistic polystylistics is a new peculiar technique of inconspicuous gradual stylistic modulation, which ultimately leads to the formation of a style that is no alien to any other ${ }^{15}$.

The plurality of attitudes toward polystylistics gives rise to numerous definitions of it. However, despite the difference in approaches, there are common features. The unifying one is the recognition that through polystylistics in a musical text, both old proven techniques and very problematic, "heuristic", new ones are put on one side of the scales. Most of the definitions also generalize the concept of an "alien word". For example, V. Medushevsky presents polystylistics as "a dispersed way of combining different style signs" $"$, V. Syrov - as "assimilating systems, where the stylistic level ... does not reveal a clear division into elements of the main (own) and subordinate (alien)",17. For S. Savenko, it's "an attempt to seriously speak the alien language, destroying any distance both ironic and tragedy"18, and M. Aranovsky defines polystylistics as "a special creative concept of style" based on "the principle of operating styles as elements with established expressiveness" ${ }^{19}$. In other words, the belonging of a sound to one or another style is evaluated as a more significant factor than the properties of the sound itself, because the main bearer of meaning is this or that style as a sign of culture - the "worldview style".

\section{The polystylistic method and contemporary composer's poetry}

The method of polystylistics turned out to be especially in tune with the circle of ideas addressed by major European composers of the 1960s and 80s. One of the most important ideas of this time is a comprehension

15 Холопова В. Музыка как вид искусства. М.: Научно-творческий центр «Консерватория», 1990.

16 Медушевский В. Стиль как семиотический объект. Советская музыка. 1979. № 3. С. 38.

17 Сыров В. О стиле Бориса Тищенко. Проблемы музыки XX века. Горький, 1977. C. 26.

18 Савенко С. Есть ли индивидуальный стиль в музыке поставангарда? Советская музыка.1982, № 5. С. 121.

19 Арановский М. Музыкальный текст: структура и свойства. М., 1998. C. $157-159$. 
of the ethical state of modern culture, and together with culture, the ethical state of modern man. The polystylistic method made it possible to expand the panorama of the musical culture of immense breadth and to make various oppositions in it in an associative way - through style allusions and quotes. Composers introduced all conceivable styles into the composition, practically reaching the exhaustion of all known style representations, at the same time, striving to confirm their author's beginning.

Based on this, we can talk about three trends that are characteristic of contemporary composer's creativity.

The first is the movement of polystylistics towards stylistic synthesis and monostyle, which, in turn, can be considered as a kind of victory of the author's style over Polycentrism of historical musical consciousness. In the XX century, polystylistics is recognized as a universal method of composer's creativity; at the same time, each of the contemporary authors finds his own path to polystylistics, forming special artistic relations with it. Thus, we can say that there are as many types of polystylistics as there are individual composer's styles, given the tendency of the latter (composer's style) towards autonomy.

This trend is confirmed in the work of the Leningrad composer Galina Ustvolskaya, whose creative method does not fit into any of the known definitions of polystylistics and requires the emergence of a new nomination. The student of D. Shostakovich, one of the key figures in Russian music of the second half of XX century, first made herself known in the 1940s and 1950s, and since then her composer's style has hardly evolved.

Ustvolskaya is an unusually solid artist. She is distinguished by its her style, the invariability of the musical language, introspectiveness, total authorization, "warlike rejection" of analogies, heritage and similarities, a focus on deepening the main ideological and style complex, and paradoxical thinking. The last feature of Ustvolskaya deserves special attention, since she is the leader in her composing poetics and manifests herself, first of all, as a combination of stylistic multidimensionality with monolithicity, the internal integrity of the style; rigor, restraint with spiritual nudity, ecstatics of musical utterances; tremendous tension with inner composure; "laconicism" with a depth of ideological content and global themes of the compositions.

One of the most remarkable features of Ustvolskaya's style is that, with his pronounced individuality, even individualistic categorization, many of the characteristic stylistic devices of other authors are reflected 
in the music of the composer. The peculiarity of the dialogue conducted by Ustvolskaya is expressed in the fact that she uses the "alien" as "own", immediately exposing it to deep assimilation. It is not so important for her that she takes many "alien words" from the already existing experience of their interpretation, from the "hands" of any other author. In most cases, Ustvolskaya does not emphasize or conceal the alienness of the borrowed.

As the musical material with which the composer's works, there are stylistic signs of distant eras, as well as authors historically close to Ustvolskaya. In the latter case, dialogic interests acquire an "inter-author character". Thus, we can say that the composer conducts a dialogue in two directions: with the historical style past and with contemporary authors. So, for example, in piano sonatas explicit associations arise with the works of Shostakovich, Hindemith, Bach, Stravinsky. Ustvolskaya relies on polyphonic ways of building text, while achieving constructive rigidity, linearism, graphic clarity of texture.

It is possible to draw parallels between the style installations of Ustvolskaya and Hindemith. Both composers generalize the characteristic genre and stylistic features of the Renaissance and Baroque music, but put them in the context of a modern artistic worldview, subordinate to the personal problems of a person of the XX century. Like Hindemith, Ustvolskaya is attracted to Bach's creativity and, above all, to Bach's melos as distinguished by semantic polyphonicity is the disclosure of the multiplicity of the whole. Prolonged tense ostinato and polyostinato, a tendency to acutely dissonant implementation of folkloric intonations are the confirmation of the Stravinsky language influence.

The characteristic polystylistic techniques in the works of Ustvolskaya include:

- a plurality of stylistic sources, which degenerates into an emphasized unity of stylistics, covering both the conceptual level and internal processes of intonational and stylistic formation;

- a peculiar treatment of the composer with the "alien word", which consists in the fact that for the author it is more important not to belong to the "word", but to its meaning; 
- the principle of genre allegory as the use of the stylistics of specific genres as carriers of semantics - certain signs and, at the same time, the removal from this stylistics ${ }^{20}$.

The second trend is related to the fact that composer's poetics poses broader tasks, primarily related to the artist's new responsibility for his social mission, as a result of which interest in the ethical parameters of composer's poetics is growing. One of the most important ideas of our time is to comprehend the moral state of modern culture, and together with culture - the moral state of modern man.

The polystylistic method made it possible to expand the panorama of the musical culture of immense breadth and to build in it various semantic oppositions in an associative way - through stylistic allusions and quotes. Composers introduced into the composition all the styles known to them, practically reaching the exhaustion of all known (historical and author's) style paradigms.

On the part of the composers themselves, what has been said is connected with the emergence of a new interest in the verbal principle as an internal compositional factor in a musical composition. So, the idea of G. Ustvolskaya, verbally stated by her in the Second and Fourth Symphonies, becomes her peculiar credo, which she follows throughout her life. In both symphonies, religious texts are used in the author's translation, indicating that G. Ustvolskaya is the artist of one idea global, infinite, eternal.

The unity of the theme addressed by the composer in his compositions allows us to consider them as a kind of macrocycle. This is also confirmed by the desire of G. Ustvolskaya for the intonational unity of most of her compositions, sometimes reaching the limit. So, for example, in sonatas one intonation complex is used, consisting of several layers: the first is the incoming movement; the second is the intonation of the descending second, the third is a jump over a wide interval. Thanks to this, all sonatas of G. Ustvolskaya can be considered as a single cycle with a culmination in the Sixth Sonata.

For A. Schnittke, the polystylistic method is associated with the pluralism of human consciousness of the XX century, with an increased intensity of information flows in this century. According to this

${ }^{20}$ Грибиненко Ю. Парадоксы полистилистики в творчестве Г. Уствольской. Научный вестник НМАУ им. П.И. Чайковского. Музичний стиль: теорія, історія, сучасність. Киев, 2004. Вып. 38. С. 220-227. 
composer, the most important thing for polystylistics is the ability to express semantic opposition within the image, create intonational tension, and combine incompatible ones. This leads to a consistent reflection in the composer's music of an expressively tragedy aesthetic sphere based on a personal experience of the paradox of being. The internal tension of the image, focusing on the leading author's intonation, the sharp accentuation of the polar principles (the semantics of positive and negative images are very clear), the special nature of the removal of musical material, which reaches the composer to alienation, deformation, the extreme sharpening of contradictions while using several genre and style complexes (the implementation of the "poetics of conflict"), introducing dramatization as a condition of psychological stress become fundamental features of A. Schnittke creative method of forming a particular type polystylistics.

In addition, the polystylistic method of this author is characterized by the application of genre allegory principle as the use of the stylistics of specific genres as carriers of semantics - certain characters and, at the same time, removal from this stylistics. This is most clearly manifested in the use of one of the key themes of the compositions of A. Schnittke the theme of the circle, which is characterized mainly by second intonations, structural symmetry, and the rotational type of melody. These are the motives: $B A C H$ (First and Second Sonatas for violin and piano) and the perpetum mobile motif (Cello Sonata, First String Quartet), built as a developing spiral, gradually covering a larger and larger range. The coincidence of the figures of the cross and the circle in the BACH motif testifies to the semantic layering of this topic. It is significant that this fact once again reveals to us the dialogical thinking of A. Schnittke. On the one hand, the theme-circle symbolizes the idea of infinity and, at the same time, isolation of being; on the other hand, the choral appearance of the theme-cross means an orientation toward a lofty goal, towards a positive spiritual result.

Convincing examples of polystylistics are also found in the compositions of Boris Tishchenko. The author's language of B. Tishchenko does not hide its imitation by others and "confronts the listener with a characteristic paradox: on the one hand, almost any sound easily reveals its origin from alien material, and on the other hand, the 
authorship of the composer is just as easily established literally by several measures of music" $" 21$.

In musicological compositions about B. Tishchenko it is often said about the stylistic layering of his music, which is confirmed by his own statement: "The more composers I learned, the more I wanted to be like them. Obviously, I am driven by a love of other people's music, rather than a desire to counterbalance it with something "own"22. The main focus of B. Katz's work on B. Tishchenko's music was the theme of "own" and "alien". Many scholars of the composer's work are moving towards establishing the original sources of B. Tishchenko's music. They note the influence of folklore, Bach polyphony, and symphonism of L. Beethoven and D. Shostakovich on him. But the composer in his compositions addresses not only the past. The inclusion of B. Tishchenko's thinking in the sphere of modern music is noted by V. Syrov: "Perhaps there is not a single stylistic device from the huge encyclopedia of musical instruments of the XX century, which would be passed by his attention and tenacious memory" 23 .

It is the constant dialogue between "own" and "alien" in the music of B. Tishchenko that allows us to define his composer's method as a polystylistic one, associated with the disclosure of the "polyphonic" possibilities of each expressive device, each figurative element.

In terms of this dialogue, the work of V. Silvestrov is substantially aesthetically close to the work of B. Tishchenko. Both for one, and for the other, the starting points in music are genre and intonation, the second being, in the end, genre-conditioned, but in a much larger historical time - on a much larger, and, therefore, more responsible, semantic scale. Both B. Tishchenko and V. Silvestrov are not so much trying to attach music to themselves, to their personal composer's attempts, as they open up the possibility of becoming familiar with it, right up to the "departure" from creative egocentrism.

Valentin Silvestrov gave this new compositional position a very clear justification. In one of his interviews, he indicated that he never engaged in literal historical reconstruction of music or speculative experiments. $\mathrm{V}$. Silvestrov recognizes two main types of music: performing and

${ }^{21}$ Кац Б. О музыке Бориса Тищенко. Опыт критического исследования. Л.: Советский композитор, 1986. С. 138.

${ }^{22}$ Там же, С. 24.

23 Сыров В. Тищенко Б. Эскиз к портрету. Музыкальная жизнь. 1989. Вып. 5. С. 23. 
author's music, and identifies performing music with an anonymous and universal principle in music, and the second with an autonomous, personal composer. However, he argues that the anonymous, universal as a "common ground" should be present in any composer's opus. "A pure personality", writes V. Silvestrov, "constantly demonstrating itself, can turn into absurdity" $"$. In music, V. Silvestrov seeks to discover indestructible, that is, constantly present moments; according to him, "the world shines through musical-bodily forms - intonation, genre", 25.

In the music of V. Silvestrov, first of all, it attracts positive meaning, purity, a sense of life, spiritual kinship between people and eras. Therefore, the melodic possibilities of the formation and development of music remain of extraordinary importance to him. The composer himself admits that he is trying to build the form as a melody; in any case, for V. Silvestrov, the melodic-canted properties of the musical language and those European styles that are associated with the development of melodic thinking are important.

Valentin Silvestrov can hardly be called a neoclassicist, although he is in dialogue with the objective, that is, with the experience of musical creativity lying beyond his personal "I". He is extremely subjective, in his own way, as a rule, senses a distance in time and, denying it, uses the alien stylistic experience. However, according to V. Silvestrov, no style experience can be too alien. He writes: "No matter what language you speak, any composition is strongly not in direct meaning, but in allegory" ${ }^{26}$. Therefore, V. Silvestrov discovers the opportunity to use "obsolete phonemes", but pronounces them as his own.

Both B. Tishchenko and V. Silvestrov are united by the absence in their work of a method of caricature-like exclusion, of a grotesque in relation to borrowed material (so characteristic, for example, for D. Shostakovich). The mystery of their polystylistic method is that they do not so much to create a distance between "own" and "alien" as they try to come closer to it, they seek in this dialogue to find a new closeness, a new degree of identity.

The third tendency can be represented as the need of a modern author for new genre forms or for a radical update of the previous ones. So,

${ }^{24}$ Сильвестров В. Музыка - это пение мира о самом себе... Сокровенные разговоры и взгляды со стороны: Беседы, статьи, письма [автор статей, составитель, собеседница М. Нестьева]. Киев, 2004. С. 13.

${ }^{25}$ Там же, C. 13.
${ }^{26}$ Там же, С. 14. 
G. Ustvolskaya, for example, does not introduce catchy genre nominations (the exception is "Compositions"). However, a new stylistic interpretation of traditional genre forms (preludes, sonatas, symphonies) leads to their complete destruction - re-arrangement. This tendency is also characteristic of the work of B. Tishchenko, although to a lesser extent.

The genre installations of V. Silvestrov and A. Schnittke are innovative and are associated, inter alia, with the introduction of new genre forms. Especially interesting in this regard are the genre preferences of Odessa composer Y. Gomelskaya. The genre forms in her work are original and do not fit into any of the traditional canons. Many of her compositions for the chamber ensemble are striking in their variety not only in terms of instrumental compositions, which is one of the characteristic features of the poetry of a modern composer, but also in terms of the symptomatic nature of the names of a number of compositions.

Basically, these trends nevertheless rely on traditional genre prototypes (they do not completely deny them), but the composer's interpretation, as well as the dramatic conditionality as the dominant in their interpretation, allows us to put forward similar new nominative trends of genre forms:

1. A mnemonic genre trend, manifested in an appeal to the genres of memorial, postlude, postscript, "herbarium";

2. A meta-musical genre trend, starting from a composer's view of traditional means of expression from the perspective of a new sonorica (represents the area of greatest composer's freedom);

3. A monodialogical genre trend, based on reflection as a phenomenon that conveys the work of consciousness (more typical of compositions using serial technology $)^{27}$.

\section{Author's models of polystylistics in the works of modern composers}

An analysis of the work of a number of composers allows us to discover how the general trends presented above are refracted in individual composer's poetics, since polystylistics as a method of

27 Грибиненко Музыкальная полистилистика в свете теории интертекстуальности: дис. ... канд. искусствовед.: спец. 17.00.03 / ОНМА имени А.В. Неждановой. Одесса, 2006. 202 с. 
composing creativity presumes the author's figure as a leading, proactive one. Hence another internal contradiction of polystylistics: on the one hand, the rules for entering a musical text are limited; on the other hand, the individual-author refraction of these rules becomes different depending on the author's style and on the stylistic sources of the compositions of this author. Thus, it becomes possible to connect polystylistics with trends in the composer's style, to discover its individuality and author's autonomy. Compositional style trends determine the varieties of polystylistics; therefore its typology becomes open: new types of polystylistics appear with new authors.

In addition, it is found that the "reading" of one or another polystylistic device depends on the trends of the individual composer's style, on the personality of the author. Musical coding is also associated with this, that is, the creation using polystylistic techniques of a rather complex concept that goes beyond the boundaries of the musical and creative process. With coding (the choice of rules and their interpretation in the composer's composition), author's models of polystylistics are associated.

Thus, linking the above with the urgent problems of composer's creativity of the last decades, in particular, with the problem of polystylistics and discovering its new sides, we come to the following conclusion.

The nature, originality and basic functional aspects of musical polystylistics are revealed and can be considered at hierarchically different levels of modern composer poetics.

The first - a meta-level that goes beyond the limits of a separate composer's consciousness - characterizes polystylistics as an aesthetic phenomenon, the main principle of which is the disclosure of the existence of music as "an anonymous mainland, on which you should try not to leave traces" ${ }^{\prime 2}$. If the creative ideas of A. Schnittke, G. Ustvolskaya and Y. Gomelskaya belong to the tragedy aesthetic sphere, then the figurative content of the works of B. Tishchenko, V. Silvestrov forms the so-called "post-tragic" sphere.

The second level is connected with the understanding of polystylistics as a principle of composer's thinking based on dialogism, on the

${ }^{28}$ Сильвестров В. Музыка - это пение мира о самом себе... Сокровенные разговоры и взгляды со стороны: Беседы, статьи, письма [автор статей, составитель, собеседница М. Нестьева]. Киев, 2004. С. 17. 
interaction of the "architectonic" and "compositional" levels of a literary text (M. Bakhtin's terminology). Dialogue is an integral part of the thinking of all authors to whom the analytical material of the work is addressed.

The general laws of compositional forms are realized through the comparison and development of various types of expressiveness, types of psychological states associated with the embodiment of the main artistic meaning of the composition. The nature of the comparisons, the strength and degree of contrast, and the ways of its implementation form the basic principles of polystylistics as the leading composer's method that meets the author's conscious intention to introduce his design into the general style context of music.

The third level - compositional - is associated with the principles of polystylistics as a symbolic expression of the plurality of musical consciousness through the introduction by the composer of intertextual techniques (quotation, allusion, stylization, collage) into the text of a musical composition, which can function as a text code leading to an understanding of the author's concept, therefore, to understanding the musical text itself. This position allowed us to introduce three new nominations in the typology of polystylistics (monological, centripetal, centrifugal), which correspond to the author's models of this phenomenon in the works of Y. Gomelskaya, V. Silvestrov, B. Tishchenko, G. Ustvolskaya and A. Schnittke.

Thus, in unity with the typology proposed by V. Kholopova, the following varieties of polystylistics can be defined:

- Diffuse, characterized by a smooth transition from one style element to another, stylistic dispersion of the original thematic complex;

- Collage, based on contrasting, sometimes sharp ("shock") juxtaposition of style elements;

- Pluralistic, which is a fairly new, peculiar method of inconspicuous gradual stylistic modulation, which leads in general to the formation of a style that is not alien to any other;

- Centripetal, enhancing the internal tension of the image, focusing on the leading author's intonation, creating the similarity of various stylistic modifications, associated with dramatization and compression of the form (typical for the works of Y. Gomelskaya and A. Schnittke);

- Centrifugal, in which the new - as the author's own intonation, found by him through a complex interaction of genre and style «signs» of music - finds itself as an update of musical memory, that is, repetition 
and renewal of musical ideas without which it is impossible to imagine a value complex of musical culture. The intonational and stylistic novelty, the authorization of musical and dramatic concepts turn out to be a different linguistic form in comparison with the forms of expression of those main known meanings, which are always addressed by the artistic consciousness, which are a constant side in the evolution of the artistic method. Most of all, this type of polystylistics corresponds to the composer's poetics of B. Tishchenko and V. Silvestrov;

- Monological, for which individual musical expressive means, which the composer chooses for himself, are important; enrichment of the language occurs through the creation of new, previously unknown techniques, or the renewal of old ones, but so that the originality of the artistic discovery obscures the connection with tradition; «monological worldview» is a contrast to the traditional view of the world around the brightly individual vision. A striking example of this type is the work of G. Ustvolskaya ${ }^{29}$.

At the fourth level, polystylistics manifests itself as a stylistic idea, a bearer of stylistic semantics as a set of authorial compositional principles that have certain, fairly stable semantic functions. Each author creates his own model of polystylistics, draws his own conclusions, which is the most important factor in the formation of the deep idea of polystylistics and allows to reach the level of aesthetic generalization. From these positions, we can talk about the presence of a new epic in the work of B. Tishchenko, new lyrics in the work of V. Silvestrov (depersonalized, but meditatively profound). A. Schnittke and G. Ustvolskaya open up new possibilities in understanding the dramatic conflict and tragedy. In their work, they outline two completely different ways of developing this idea: old believer truthfulness leading to neoarchaics becomes an integrating principle in the poetics of G. Ustvolskaya; faustianism, postromantic skepticism is distinguished by the semantic system of music by A. Schnittke. Features of the author's style of Y. Gomelskaya can be defined as post-neoromantic.

Turning to the material of the study as a whole, we can distinguish two more inner-opposition pairs of tendencies in the development of the polystylistic method: tendencies of justification - unjustification as an

29 Грибиненко Музыкальная полистилистика в свете теории интертекстуальности: дис. ... канд. искусствовед.: спец. 17.00.03 / ОНМА имени А.В. Неждановой. Одесса, 2006. 202 с. 
artistic result of style compatibility (incompatibility) of textual material, which are sometimes directed towards paradox, grotesque, cartoon; intentional tendencies - unintentions associated with the occurrence of additional effects, some of which were not foreseen by the author and appear already in the context of listening perception.

\section{CONCLUSIONS}

Polystylistics as a composer's method expresses a certain dialogical position, for which the interaction of "own - alien" and "alien - own" is typical (however, typical of generating any text, which, in particular, is highlighted by M. Aranovsky in his study of structure and properties of musical text). Polystylistics goes through various phases of the dialogue: from submission to the authority of the "alien" - through the development of its logical apparatus - to self-legitimacy in relation to it, to the transformation of the "alien initiative" into the own. Various author's positions in relation to the textological material within the composition allow us to outline the main trends in polystylistics, namely:

- assimilation (consent, removal of the author's distance in relation to "alien" textual material);

- discrepancy (exclusion, partial distance in relation to "alien" textual material);

- identification (removal, rejection of the "alien", up to alienation);

- rejection (active rejection, deformation, breaking the borrowed stylistic model).

It is musicological analysis that allows us to identify the artistic significance of unintentional polystylistics as an important indicator of deep semantics (L. Hakobyan). This does not negate our definition of polystylistics as a conscious method of composer's poetics aimed at generalizing and integrating style material by creating a system of musical and stylistic references.

We conclude that polystylistics is a necessary category of musicology, which is declared directly by composer's poetics, that is, prompted by the experience of modern authors. As a musicology category, polystylistics opens up a wide range of cultural meanings, allowing it not only to enter the system of musical-cultural-scientific terms, but also to be determined by them in a certain respect. 


\section{SUMMARY}

The aim of our article is to identify the nature and levels of manifestation of the polystylistics phenomenon in the compositions of modern composers, which is the source of musical creative concepts in the semantic field of modern musical culture and provides a dialogue of styles, genres, forms, etc. It provides basic information about the interpretation of the term "polystylistics" in musicology, and also compares the methods and principles of polystylistics in connection with the main trends of modern composer's poetics.

The study proposes and substantiates the typology of musical polystylistics. In order to justify the typology of the phenomenon of polystylistics, the study pays special attention to the analysis of its author's models, based on chamber and instrumental compositions by Russian and Ukrainian composers. The identification of special types of polystylistics allowed us to introduce new nominations that reveal the essence of the creative method of the studied composers.

The mechanism of the implementation of the polystylistic method is considered on the example of music by G. Ustvolskaya, A. Schnittke, B. Tishchenko, as well as the compositions of modern Ukrainian composers - V. Silvestrov and Y. Gomelskaya.

\section{REFERENCES}

1. Арановский М. Музыкальный текст: структура и свойства. M., 1998. 343 c.

2. Бахтин М. Собрание сочинений в семи томах. Проблемы поэтики Достоевского. Том 6. М.: Русские словари, 2002. 505 с.

3. Грибиненко Музыкальная полистилистика в свете теории интертекстуальности: дис. ... канд. искусствовед.: спец. 17.00.03 / ОНМА имени А.В. Неждановой. Одесса, 2006. 202 с.

4. Грибиненко Ю. Парадоксы полистилистики в творчестве Г. Уствольской. Научный вестник НМАУ им. П.И. Чайковского. Музичний стиль: теорія, історія, сучасність. Киев, 2004. Вып. 38. C. 220-227.

5. Григорьева Г. Стилевые проблемы русской советской музыки второй половины XX века. М., Советский композитор, 1989. 208 с.

6. Кац Б. О музыке Бориса Тищенко. Опыт критического исследования. Л.: Советский композитор, 1986. 166 с.

7. Медушевский В. Стиль как семиотический объект. Советская музыка. 1979. № 3. С. 30-39. 
8. Назайкинский Е. Принцип единовременного контраста. Русская книга о Бахе. М.: Музыка, 1985. С. 265-294.

9. Назайкинский Е. Стилистика музыкального произведения. URL: www.harmony.musigi.dunya.az/harmony/rus

10.Савенко С. Есть ли индивидуальный стиль в музыке поставангарда? Советская музыка.1982, № 5. С. 117-122.

11.Сильвестров В. Музыка - это пение мира о самом себе... Сокровенные разговоры и взгляды со стороны: Беседы, статьи, письма [автор статей, составитель, собеседница М. Нестьева]. Киев, 2004. 265 c.

12.Сыров В. О стиле Бориса Тищенко. Проблемы музыки XX века. Горький, 1977. С. 21-27.

13. Сыров В. Тищенко Б. Эскиз к портрету. Музыкальная жизнь. 1989. Вып 5. С. 16-24.

14.Холопова В. Композитор Альфред Шнитке. Челябинск: «Аркаим», 2001. 255 с.

15.Холопова В. Музыка как вид искусства. М.: Научнотворческий центр «Консерватория», 1990. 260 с.

16. Холопова В., Чигарева Е. Альфред Шнитке: Очерк жизни и творчества. М.: Советский композитор, 1990. 350 с.

17.Энциклопедический музыкальный словарь. М., Советская энциклопедия, 1990. 672 с.

\section{Information about the author: Grybynenko Ju. O.,}

Ph.D. in the History of Art, Assistant Professor at the Department of Music History and Musical Ethnography, Odessa National A. V. Nezhdanova Academy of Music 63, Novoselsky str., Odessa, 65023, Ukraine 